\title{
Comparative Study between Organic and Mineral Fertilization of Mulberry Trees and Its Effect on Cocoon Parameters of Silkworm
}

\author{
Mohamed KamelHamzah \\ Plant Protection Dept., Fac. of Agric., AL-Azhar Univ., Nasr City, Cairo, Egypt. \\ Correspondenceauthor: mohamedhamzah70@yahoo.com
}

\begin{abstract}
The work was carried out at the Plant Protection Department, Faculty of Agriculture, AL-AzharUniv, Nasr City, Cairo, Egypt. In order to carry outcomparative study between organic and mineral fertilization for mulberry trees and its effect on cocoon parameters of silkworm. Silkworm is a monophagous insect that drives almost all required nutrients for its growth and development from mulberry leaves. Treated mulberry Morusalbavarrosa (local variety) leaves were offered to Thiol of silkworm larvae four times per day. Theobtained results showed that the feeding of larvae on leavesmulberry of trees treated with green manure increased the fresh cocoon weight $(0.796,0.680 \mathrm{~g})$, cocoon shell weight $(0.162,0.126 \mathrm{~g})$, pupa weights $(0.678,0.568 \mathrm{~g})$, cocoon shell ratio $(24.98$, $23.10 \mathrm{~g})$, silk gland $(0.361)$, cocooning percentages $(89.6,78 \%)$ and silk productivity $(1.62,1.29 \mathrm{cg} / \mathrm{days})$.
\end{abstract}

Key words: silkworm- mulberry leaves- fertelization- bombyx mori

\section{Introduction}

Mulberry is a perennial, woody and deciduous plant, belonging to the family Moraceae and genus Morus native of China (Ramesh et al. 2014). Among 150 Morus species, only 68 species were given more importance, based on their use in silkworm rearing, medicinal value and sweetness of fruit (Rao et al. 2013).Mulberry, the sole food Plant of silkworm plays vital role in the growth and the development of silkworm and in turn the silk production, Leaf quality and quantity not only influence the silkworm growth and development, but also the cocoonproduction, quality and quantity of raw silk. Chemical constituents in plants provide information for determining the host range in phytophagous insects (Chapman 2003). Nutrition plays a vital role in sericulture; itimproves the growth, development, health, food consumption and conversion of silkworm thereby improving the commercial traits. Application of the required nutrient in the required amount to mulberry plant is very essential for the successful silkworm growth and cocoon production. The present studyisaimed to comparative study between organic and mineral fertilization for mulberry trees and its effect on cocoon parameters and its impact on cocoon parameters of silkworm.

\section{Materials and Methods}

The experiment was carried in the Department of Plant Protection, Faculty of Agriculture. ALAzharUniv, Nasr City, Cairo, Egypt.

Treatment details:

1- The organic manure is added at $8 \mathrm{~m}^{3} /$ fedan for one batch before forming the leaves in the following spring season.
2- Mineral complex fertilizer NP2o-K2o (17-19-10) the mineral fertilizer was added at one time $100 \mathrm{~g} /$ tree and the trees were irrigated. In addition to untreated trees without any fertilizers.

\section{Silkworm rearing technique:}

Eggs of the silkworm Thio1 hybrid were imported from Thailand, rearing was carried out under hygienic conditions $\left(26 \pm 2{ }^{\circ} \mathrm{C}\right.$ and $70 \pm 5 \quad \mathrm{RH}$.) according toKrishnaswami et al. (1973). During the spring season of 2017 , eggs were incubated at $24^{\circ} \mathrm{C}$ and $80 \%$ $\mathrm{RH}$. The larvae were covered with plastic sheets and surrounded by witted spongy strips to offer suitable conditions for young larval instars ( $1^{\text {st }}-3^{\text {rd }}$ instars $)$.

The new hatched larvae were fed on Morusalbavarrosamulberry leaves till pupation. After each moulting, cleaning nets with holes ( $3 \mathrm{~mm} \times 3 \mathrm{~mm}$ ) were used for removing the dried leaves and feces during young larval instars. At the end of the $5^{\text {th }}$ larval stadium, the larvae stop feeding and start to spin cocoon.Collapsible frames were used as montages for cocoon spinning. After ten days of spinning, cocoons were collected.

Fresh cocoon weight: Fifty fresh cocoons were cut and pupae were sexed.

Cocoon Shell weight: The previous cocoons, after removing the pupae and cleaning them from exuviae, were weighed and the average weight was calculated. Cocoon shell ratio \%: was calculated for both sexes in each treatment according the formula adopting by (Krishnaswami et al. 1973).

Cocoon Shell weight $(\mathrm{g})$

Cocoon Shell ratio $(\%)=$

Fresh Cocoon weight (g)

Pupae Weight: Pupae of the previous cocoons of each treatment after being sexed, were removed from 
cocoons and weighed separately, the average weight was calculated.

Silk productivity: was calculated using the following formula and expressed as cg/day (Iyengaret al. 1983).

\section{Silk productivity per day $(\mathrm{cg} / \mathrm{day})=$}

Cocoons shell weight $(\mathrm{cg})$

Fifth instar duration (day)

Statistical analysis of data:

Economical parameters data were statistically analyzed using DUNCAN, D. B. (1955) implemented by the (Costat, 1988) software program.

\section{Results and Discussion}

The obtained results in table (1) show that fresh cocoon weight, cocoon shell weights and cocoon shell ratio differed from male to female, being heavier for male than female. Also, feeding on treated mulberry leaves with organic and mineral supplements resulted heavier cocoons in both sexes. The weights of fresh cocoons recorded $0.796,0.680$ and $0.714,0.707 \mathrm{gm}$ for male and female as feeding on leaves fertilized by mineral and manure fertilizers; respectively. Whereas the means were 0.657 and $0.645 \mathrm{~g}$ in untreated for male and female; respectively.

Results of cocoon shell weights and cocoon shell ratio had the same trend of the cocoon fresh weights. Supplementation with mineral fertilization led to increasing in cocoon shell of male and female. The obtained means were $0.162,0.126 \mathrm{~g}$ and 0.159 , 0.124 gwith mineral and organic fertilization treatments, and $0.133,0.120 \mathrm{~g}$ in untreated for male and females; respectively, the cocoon shell ratio recorded 24.98, $23.10 \%$ for male and femalewith mineral fertilization treatments, and $22.82,22.28 \%$; respectively, compared to untreated; $18.08,16.95 \%$; respectively. Statistical analysis showed significant difference between treatments.

Application of organic fertilizers to mulberry had a significant influence on cocoon yield, shell ratio, silk productivity and single cocoon filament length (Sannappaet al. 2005). Nutrition plays a pivotal role in sericulture. It improves the growth, development, health, feed consumption and conversion of silkworm thereby improving the commercial traits. Silkworm is a monophagous insect that drives almost all required nutrients for its growth and from mulberry leaf. Applicationof the required nutrient in a balanced amount to mulberry plant is, therefore, very essential for the successful silkworm growth and cocoon production Mary and Saravanan (2010) and Waktole and Bhaskar (2012).

Chemical, bio-fertilizers andtheir mixture increased fresh cocoon weight, cocoon shellweight, cocoon shell ratio, total larval duration,hatchability, silk gland weight, filament length andfilament weight and filament size. While, application bybio-fertilizer resulted in better values for cocoon shellratio, cocoon percentage, larval weight, total larvalduration, silk gland length and filament length. Bothchemical and bio fertilizes exhibited better values for pupalweight. From the previous mentioned results fertilizersmay be arranged from the side of its importance tomulberry trees and silkworms as follows: Biofertilizers,mixture of both (chemical and biofertilizers) and finallythe chemical fertilizers (ElKhayatet al., 2013).

Pupa weights (g) and Silk productivity (cg/days).

Male pupal weights resulted from larvae fed on leaves obtained from trees treatedmineral manure and organic manurefertilizers were 0.678 and $0.591 \mathrm{~g}$; respectively. Whilefemalepupal weights were 0.568 and $0.550 \mathrm{~g}$; respectively. However, pupal weights were $0.512 \& 0.490 \mathrm{~g}$ for male and female in untreated; respectively. Statistical analysis showed significant difference between treatments.

Silk productivity of B.mori larvae fed on mulberry leaves treated with mineral fertilization were 1.62 and 1.29 (cg/days) for male and female; respectively. While the mean percentages in leaves treated with organicmanure were 1.36 and $1.25(\mathrm{cg} /$ days) for male and female; respectively, compared to untreated which were 1.13 and 1.10 (cg/days) for male and female; respectively.The differences were significant.

Observed that combined application of sericulture by-products along with fertilizers registered highest silk productivity, Maximum cocoon yield was obtained in T12 $(53.96 \mathrm{~kg})$ followed by T11 $(51.76 \mathrm{~kg})$. But, other treatments such as T1 (43.52 $\mathrm{kg})$, T5 $100 \%$ recommended $\mathrm{N}$ through Castor oil cake $(43.95 \mathrm{~kg})$ and $\mathrm{T} 7(43.91 \mathrm{~kg})$ were on par with each other with respect to cocoon yield (Rajannaet al.,2000). 
Table1. Effect of silkworm larvae feeding on mulberry trees treated by organic and mineral fertilizers on some economical parameters of silkworm

\begin{tabular}{|c|c|c|c|c|c|c|c|c|c|c|c|c|}
\hline \multicolumn{9}{|c|}{ Economical parameters } & \multirow{2}{*}{\multicolumn{2}{|c|}{$\begin{array}{l}\text { Silk productivity (cg/days) } \\
\text { (Silk prod) }\end{array}$}} & \multirow{2}{*}{\multicolumn{2}{|c|}{$\begin{array}{c}\text { Cocooning } \\
\text { Percentage } \\
\% \\
\text { (CP) }\end{array}$}} \\
\hline \multirow{2}{*}{ Treatments } & \multicolumn{2}{|c|}{$\begin{array}{l}\text { Fresh } \\
\text { cocoon weights/g } \\
\text { (F.C.W) }\end{array}$} & \multicolumn{2}{|c|}{$\begin{array}{l}\text { Cocoon } \\
\text { shell weights/g } \\
\text { (C. S.W) }\end{array}$} & \multicolumn{2}{|c|}{$\begin{array}{l}\text { Cocoon } \\
\text { shell ratio\% } \\
\text { (C.S.R) }\end{array}$} & \multicolumn{2}{|c|}{$\begin{array}{c}\text { Pupae } \\
\text { weight/g }\end{array}$} & & & & \\
\hline & $\underset{\substack{\lambda \\
\text { Male }}}{\cos }$ & $\begin{array}{c}\text { Female } \\
q \\
q\end{array}$ & $\underset{\substack{\text { Male }\\
}}{\text { Mal }}$ & $\begin{array}{c}\text { Female } \\
\stackrel{+}{+}\end{array}$ & 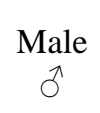 & $\begin{array}{c}\text { Female } \\
q \\
+\end{array}$ & $\underset{\hat{\sigma}}{\text { Male }}$ & $\begin{array}{c}\text { Female } \\
q\end{array}$ & $\underset{\substack{\text { Male } \\
\text { Mal }}}{\cos }$ & $\begin{array}{c}\text { Female } \\
q \\
q\end{array}$ & 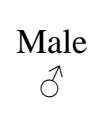 & $\begin{array}{l}\text { Female } \\
\quad q\end{array}$ \\
\hline \multirow[t]{2}{*}{ Organic manure } & $0.714 \mathrm{ab}$ & $0.707 \mathrm{a}$ & $0.159 \mathrm{a}$ & $0.124 \mathrm{a}$ & 22.82 & 22.28 & $0.591 b$ & $0.550 \mathrm{a}$ & $1.36 \mathrm{~b}$ & $1.25 \mathrm{a}$ & 80.5 & 71 \\
\hline & & & & & & & & & $1.62 \mathrm{a}$ & & & \\
\hline Mineralfertilizer & $0.796 \mathrm{a}$ & $0.680 \mathrm{a}$ & $0.162 \mathrm{a}$ & $0.126 \mathrm{a}$ & 24.98 & 23.10 & $0.678 \mathrm{a}$ & $0.568 \mathrm{a}$ & & $1.29 \mathrm{a}$ & 89.6 & 78 \\
\hline Un-treated & $0.657 \mathrm{~b}$ & $0.645 \mathrm{a}$ & $0.133 b$ & $0.120 \mathrm{a}$ & 18.08 & 16.95 & $0.512 \mathrm{c}$ & $0.490 \mathrm{a}$ & $1.13 \mathrm{c}$ & $1.10 \mathrm{~b}$ & 68 & 68 \\
\hline L.S.D. & 0.092 & 0.085 & 0.012 & 0.018 & & & 0.053 & 0.075 & 0.136 & 0.139 & & \\
\hline
\end{tabular}

Means followed by the same letter in the same column are not significantly differently. 
Cocooning Percentages

Cocooning Percentages of silkworm larvae fed on mulberry leaves treated with mineral fertilization were 89.60 and $78 \%$ for male and female; respectively, While they were 80.5 and $71 \%$ for male and female; respectively, in case of organic fertilization. While the mean percentages in untreated leaves were $68.00 \%$ for male and female; respectively,statistical analysis showed un-significant difference between treatments.

The diagnostic experiment showed that $\mathrm{N}, \mathrm{K}$, and $\mathrm{P}$ were the most important nutrients with respect to mulberry-leaf yield, leaf sugar, and leaf essential and total amino acid concentrations. Although reducing the supply of $\mathrm{Mg}, \mathrm{S}$, and $\mathrm{B}$ did not significantly decrease leaf yields, it significantly impaired the concentrations of leaf sugars and essential and total amino acids. These reductions may affect cocoon quality by reducing silkworm larval and cocoon weight. Treatments with reduced $\mathrm{N}$ - and P-fertilizer application resulted in decreased leaf fat concentrations, while a reduced $\mathrm{K}$ supply slightly increased it. In contrast, when $\mathrm{Mg}, \mathrm{S}$, and $\mathrm{B}$ fertilization was reduced, this significantly increased leaf fat concentration, Fang Chen (2009).

\section{Chemical analysis}

Table 2.Composition between treated and untreated leaves as regard the amounts of total protein, chlorophylls a and $\mathrm{b}$ in treated and untreated mulberry leaves and total protein in silkworm larvae.

\begin{tabular}{cccc}
\hline & & & \\
Treatments & $\begin{array}{c}\text { Total protein }(\mathrm{mg} / \mathrm{g}) \\
\text { silkworm larvae }\end{array}$ & & Chlorophyll (mg/g) in mulberry leaves \\
\cline { 3 - 4 } Mineral manure & 9.37 & Chlorophyll a & Chlorophyll b \\
\hline Organic fertilizer & 8.37 & 26.98 & 27.41 \\
\hline Untreated & 6.78 & 20.07 & 20.96 \\
\hline
\end{tabular}

\section{References}

CHAPMAN, H. D. and R. E. PRATT (1962): Methods of Analysis for Soil, Plants and Water. Dept. of Soil, Plant Nutrition, Univ. of California, U.S.A. (January 1962 - Volume 93 Issue 1 - ppg 68)

CHAPMAN, H. D. and R. E. PRATT (1962): Methods of Analysis for Soil, Plants and Water. Dept. of Soil, Plant Nutrition, Univ. of California, U.S.A. (January 1962 - Volume 93 Issue 1 - ppg 68)

COSTAT SOFTWARE (1988): Microcomputer program analysis, CoHort software, Berkely, CA, USA.

DUNCAN, D. B (1955): Multiple range and multiple F tests, Biometrics, 11, 1-42.
Chemical analysis was carried out to estimate Chlorophylls $\mathrm{a}$ and $\mathrm{b}$ by using the method of Lichtenhaler and Wellburn (1983). Total proteins were estimated in leaves and larvae according to Chapman Pratt (1962). The data in table (2) show that the total protein in larvae of Thio1 hybrid fed on Mineral manure and organic fertelizers 9.37, 8.37 compared to untreated $6.78 \mathrm{mg} / \mathrm{g}$; respectively. The data in table (2) clarify that the Chlorophyll ( $a$ and b) were differed in both treated and untreated mulberry trees by organic manure. Chlorophyll $a$ and $b$ in treated mulberry leaves with mineral manure and organic manure was $(26.98,27.41 \mathrm{mg} / \mathrm{g}$; and 23.04 , $20.96 \mathrm{mg} / \mathrm{g}$ compared to untreated were 21.07 and $20.78 \mathrm{mg} / \mathrm{g}$; respectively, it was higher than that of mulberry leaves treated with mineral manure $(23.04$, $20.96 \mathrm{mg} / \mathrm{g}$, respectively, and affect consequently. the total protein in larvae of Thio1 hybrid fed on mineral manure and organic fertilizers and untreated 6.78 $\mathrm{mg} / \mathrm{g}$; respectively

Recommendation, results indicate that poor soil fertility and unbalanced fertilization were the main factors limiting mulberry leaf yield and quality in. The results obtained during this work indicate the superiority of larvae on mulberry leaves treated with organic or mineral fertilizer. 
KRISHNASWAMI, S.; M. N. NARASIMHANNA.; S. K. SURYANARAYANA and S. J. KUMARARA (1973): Manual on sericulture-2, Silkworm Rearing, (FAO, Rome, 42-43).

LICHTENHALER, K. H. and A. R. WELLBURN (1983): Determinations of total carotenoids and chlorophylls a and b of leaf extracts indifferent solvents. (In: Biochem. Soc. Trans.60 3rd Meeting Liverpool, 11: 591-592).

MARY, L. C. $L$ and N. A. SARAVANAN (2010):Influence of bio-fertilizers on mulberry and silkworm production.(Journal of Ecobiology, 27(1/2): 197-199).

RAMESH, H.; V. SIVARAM and V. Y. MURTHY (2014): Antioxidant and medicinal properties of mulberry (Morus sp.): (A review. World J. Pharm. Res., 3(6): 320-343).

RAJANNA, B. H.; K. P. CHINNASWAMY.; R. GOVINDAN.; B. SANNAPPA, and S. R. SUNDAR (2000): Effect of sericulture by- products and other organic manures on leaf yield and elemental composition of mulberry. (Bull. Ind. Acad. Seric., 4: 70-74).

RAO, R. M. BORPUZARI and A. MANJULA (2013): Scope of pre-breeding in mulberry crop improvement-a review. (Sci. Weekly, 1(6): 1-18).

SANNAPPA, B.; C. DORESWANY.; N. RAMAKRISHNA.; R. GOVINDAN and K. S. SAGADISH (2005): Influence of sources of organic manures applied to 5-36 mulberry on rearing performance of silkworm (PM x GSR-2). (Progress of Research in Organic Sericulture and Seri-by product Utilization, pp: 131-136).

WAKTOLE, $S$ and R. N. BHASKAR (2012): Effect of bio-inoculants applied to M5 mulberry under rain-fed condition on growth and cocoon traits performance of silkworm, Bombyxmori L. (Momona Ethiopian Journal of Science, 4(2): 29-39). 


\section{دراسة مقارنة بين التسميد العضوي والمعدني لأشجار التوت وأثرها على صفات شرانق دودة الحرير. محمد كامل عبدالصمد حمزة عبيد}

قسم وقاية النبات - كلية الزراعة بالقاهرة - جامعة الأزهر.

complex fertilizer NP2O-K20 من خلال النتائج المتحصل عليها يتضح أن إضافة الأسمدة العضوية (السماد البلدى) والمعنيه (-19-17) (10)لأثجار التوت له نأثيره على محصول الاوراق من حيث الجودة والكمية حيث ان السماد يوفر للثجرة العناصر الغذائية الناقصة فى التربه أو

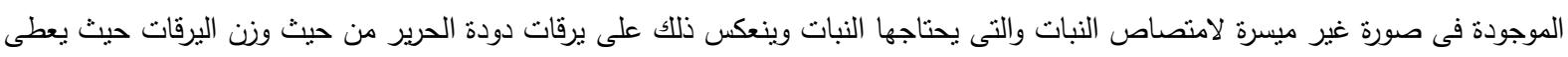

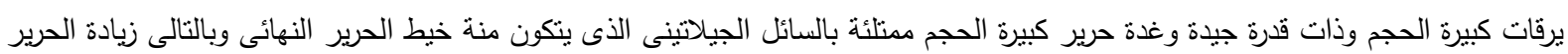
الناتج من اليرقات. تم إنجاز هذا البحث بمزرعة التوت الخاصة بقسم وقاية النبات بكلية الزراعة بالقاهرة جامعة الأزهر - بمدينة نصر ـ تم جمع الأوراق المعاملة

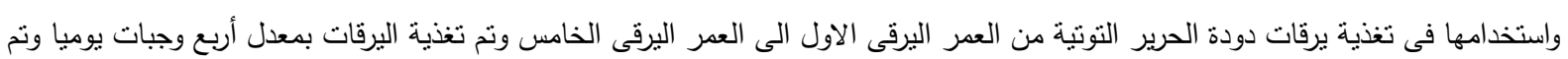

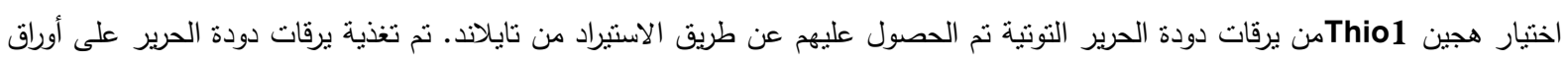

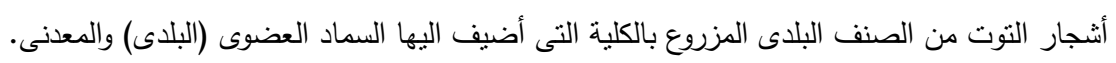

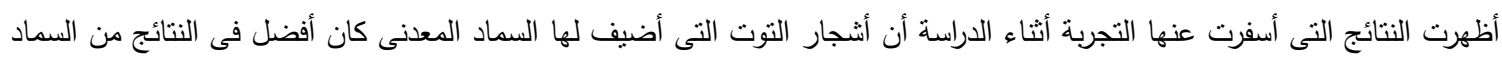

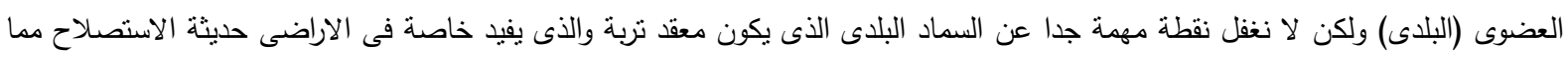

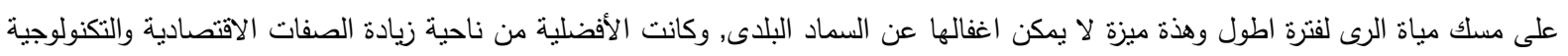
ليرقات دودة الحرير . 